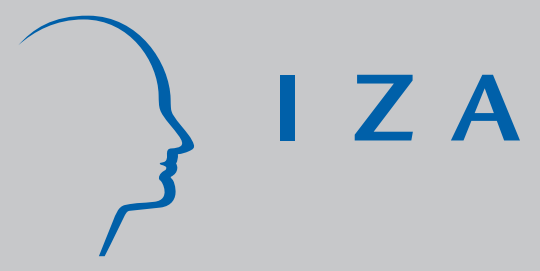

IZA DP No. 538

\title{
The Pension Transfer Program
}

Mike Orszag

Dennis Snower

J uly 2002 


\title{
The Pension Transfer Program
}

\author{
Mike Orszag \\ Watson Wyatt and IZA Bonn \\ Dennis Snower \\ Birkbeck College, University of London, \\ CEPR and IZA Bonn \\ Discussion Paper No. 538 \\ July 2002 \\ IZA \\ P.O. Box 7240 \\ D-53072 Bonn \\ Germany \\ Tel.: +49-228-3894-0 \\ Fax: +49-228-3894-210 \\ Email: iza@iza.org
}

This Discussion Paper is issued within the framework of IZA's research area Welfare State and Labor Market. Any opinions expressed here are those of the author(s) and not those of the institute. Research disseminated by IZA may include views on policy, but the institute itself takes no institutional policy positions.

The Institute for the Study of Labor (IZA) in Bonn is a local and virtual international research center and a place of communication between science, politics and business. IZA is an independent, nonprofit limited liability company (Gesellschaft mit beschränkter Haftung) supported by the Deutsche Post AG. The center is associated with the University of Bonn and offers a stimulating research environment through its research networks, research support, and visitors and doctoral programs. IZA engages in (i) original and internationally competitive research in all fields of labor economics, (ii) development of policy concepts, and (iii) dissemination of research results and concepts to the interested public. The current research program deals with (1) mobility and flexibility of labor, (2) internationalization of labor markets, (3) welfare state and labor market, (4) labor markets in transition countries, (5) the future of labor, (6) evaluation of labor market policies and projects and (7) general labor economics.

IZA Discussion Papers often represent preliminary work and are circulated to encourage discussion. Citation of such a paper should account for its provisional character. A revised version may be available on the IZA website (www.iza.org) or directly from the author. 
IZA Discussion Paper No. 538

July 2002

\section{ABSTRACT}

\section{The Pension Transfer Program}

The paper examines the following pension reform strategy that aims to defuse the pension time-bomb without giving rise to intergenerational conflict. Let people with rights to public pensions have the option of using a portion of their potential pensions to provide employment vouchers for employers that hire them. The policy is entirely voluntary; only those older workers and those employers who wish to avail themselves of this option will do so. The older workers retain the right to draw their public pensions and the employers have the right not to employ them. In effect, the policy involves taking some of the funds that would have financed public pensions and using them to provide employment subsidies. When a person takes advantage of the PTP over a given period of time, he loses his pension rights over that span and gains improved employment opportunities instead.

JEL Classification: $\quad \mathrm{H} 1, \mathrm{H} 2, \mathrm{H} 6$

Keywords: pensions, employment subsidies, early retirement, inter-generational redistribution

Dennis Snower

Department of Economics

Birkbeck College

University of London

7 Gresse Street

London W1P 1LL

UK

Tel.: +44 (207) 6316408

Fax: +44 (207) 6316416

Email: dsnower@economics.bbk.ac.uk 


\section{Introduction}

The public pension systems in most OECD countries are headed to go into rising deficit. If this gap between pension obligations and pension contributions is left unchecked, these deficits will inevitably crowd out investment in physical and human capital and other sources of economic growth. Public pension systems are usually financed through payroll taxes. Financing the rising deficits through rising payroll taxes would inevitably reduce the living standards of employed people and distort their incentives to work and save.

Thus policy makers in many OECD countries recognize the need to reduce public pension obligations. But reducing state pension pay-outs is tantamount to a forcible redistribution of resources from retired people to employed ones. As the OECD populations age, the electoral support for such a policy - already very weak - may be expected to decline. Many policy makers in the OECD agree that public pension systems have frequently been misdesigned, giving potential pension excessive incentives to retire from the labor force. What is required is a pension reform strategy that defuses the pension time-bomb without giving rise to intergenerational conflict.

This paper explores the following approach to this policy challenge. Let people with rights to public pensions have the option of using a portion of their potential pensions to provide employment vouchers for employers that hire them. The policy is entirely voluntary; only those older workers and those employers who wish to avail themselves of this option will do so. The older workers retain the right to draw their public pensions and the employers have the right not to employ them.

In effect, the policy involves taking some of the funds that would have financed public pensions and using them to provide employment subsidies. Since funds are transferred from pension support to employment support, we call this policy the pension transfer program, or PTP for short. When a person takes advantage of the PTP over a given period of time, he loses his pension rights over that span and gains improved employment opportunities instead. Older workers will avail themselves of the PTP only if the remuneration they receive from employers is sufficiently high to warrant giving up their public pension rights over a given period.

Similarly, employers will avail themselves of the program only if the resulting labor cost is sufficiently low to make the older workers profitable. In effect, the PTP is designed to improve the wage offers to older workers (since employers can 
afford to pay more for workers who are subsidized) and reduce the employers' costs (since only part of the employment subsidy is passed on to the workers in the form of higher wages). The difference between what the older workers receive and what the employers pay is the portion of the potential pensions that has been transferred to employment vouchers.

If the legal maximum retirement age remains unchanged, then the PTP may be expected to discourage early retirement. On the other hand, if the PTP is combined with an increase in the retirement age, its effectiveness is of course enhanced.

Note that only a fraction of the available pension is transferred. The rest is recouped by the government. In this way, the PTP becomes an instrument that permits the government to reduce its pension obligations.

In short, the government gains since it reduces its pensions deficit; participating employers gain since their labor costs fall; and participating workers are better off since the resulting wage offers compensate them for the loss of their pension rights.

It is important to note that the public-sector pension arrangements of some OECD countries could be interpreted as implicitly embodying some form of the PTP. In the UK, for example, the employment decisions of people above the official retirement age do not affect their pension rights, i.e. the government clawback of pension payments is zero. The U.S. Social Security system is similar in practice, with the difference that the government claws back a portion of the pension payments while people work, but compensates them in an actuarially fair manner through higher benefits once they have stopped working. These systems could be interpreted as an extreme case of the PTP in which the government recoups nothing of the pension, and the pensioner is free to pass a portion of his or her pension on to a prospective employer in the form of lower wage claims. In Norway and Denmark, on the other hand, the government claws back virtually all the pension payments of working people.

Over the entire spectrum of pensionable persons (including early retirees) in the OECD, the implicit tax rate on work is particularly low in Switzerland (around zero percent), Iceland (2\%), Canada (5\%), USA (12\%), Norway (14\%), and the UK (15\%); the rate lies in an intermediate range in , New Zealand (27\%), Japan (28\%), Ireland and Germany (33\%), Portugal and Austria (34\%), Belgium (37\%), Finland (42\%), and Spain (45\%); and the implicit tax rate is in the high range in France (49\%), Denmark (51\%), Netherlands (57\%), Luxembourg (64\%), and 
Italy $(79 \%){ }^{1}$

We now proceed to present a very simple model of how the PTP may work. We begin by examining the possible effects of the policy when it is combined with an increase in the retirement age, and then consider how it may affect early retirement.

\section{A Simple Model of the PTP with a Raise Retirement Age}

We now present a very simple model that illustrates how the transfer of pensions to employment vouchers affects employment and retirement, and how the optimal employment voucher policy could be determined.

Suppose that pensionable workers can be in one of two states: employed or retired. Let $h$ be the probability that such a worker will be hired. We assume that pensionable workers live for one period of analysis and that the pensioned population $Z$ is assumed constant through time. Let $N$ be the employment level of pensionable workers in period $t$ and $P$ be the retirement level in that period.

Then the employment level is

$$
N=h Z
$$

and the retirement level is

$$
P=(1-h) Z \text {. }
$$

Now consider the effect of the PTP. For simplicity, we focus on a part of the program that involves raising the maximum retirement age and targeting the employment vouchers at people who were above the previous maximum retirement age but are now beneath the current maximum. Let each pensioned worker in this target group receive an employment voucher $V$, granted for the period of pensionable age. Define the voucher ratio $v=V / B$ as the ratio of the employment voucher to the pension payment. Then, for simplicity, let the hiring rate be proportional to the voucher ratio:

$$
h(v)=\eta v, \quad \eta>0
$$

In the absence of the PTP, the hiring rate is zero since all pensioners are out of the labor market. The coefficient $\eta$ called hiring responsiveness (the effect of the

\footnotetext{
${ }^{1}$ See OECD (1999).
} 
voucher on the hiring rate, where $\eta$ stands for employment). The hiring function is a reduced form; it represents the degree to which the employment voucher affects the employees' incentives to work and the firms' incentives to employ, taking into account heterogeneity of jobs and workers, self-selection bias, and so on. ${ }^{2}$

Suppose that the government's policy problem is to find the magnitude of the voucher that maximizes the employment of the target group and, if possible permits it to recoup a given proportion $g$ of the average pension per capita, without making any pensioner worse off.

We specify the government budget constraint as follows. Since the number of pensionable people hired in each period is $h(v) Z$, the "voucher cost" (total cost of vouchers to the government) is $V h(v) Z+g B$. This cost must be set against the "voucher revenue", which is the total amount that the government saves on pension payments due to the voucher-induced rise in the employment rate. Let $P(V)$ and $P(0)$ be the long-run retirement rates in the presence and absence of the voucher, respectively. Let the pension payment $B$ per capita be a positive constant, and let the tax the government receives on income earned per capita be $T$. Then the amount that the employment vouchers enable the government to save on pension payments is $(B+T)(P(0)-P(V))$.

The government budget constraint (GBC) specifies that the voucher revenue $((B+T)(P(0)-P(V))$, from the government's reduced pension payments and increased tax receipts) minus the voucher cost $(V h(v) Z)$ must be equal to the sum the government recoups $(g B P(0))$ :

$$
V h(V) Z+g B P(0)=(B+T)(P(0)-P(V))
$$

Note that in the absence of the voucher, $h=0$ and thus $P(0)=Z$; and in the presence of a positive voucher, $P(V)=(1-h) Z=(1-\eta v) Z$. Let $\tau=T / B$ be the "tax ratio," i.e. the ratio of the per capita tax to the per capita pension benefit. Expressing equation (4) in units of the pension payment per capita (i.e. dividing both sides of the GBC by $B Z$ ), the GBC becomes $\eta v^{2}-(1+t) \eta v+g=0$. Since employment is an increasing function of the voucher ratio, the larger root of this equation is the one that meets the government's objective of maximizing

\footnotetext{
${ }^{2}$ For this reason it is unnecessary for us to specify how the hiring rate differs across groups of workers.
} 
employment: ${ }^{3}$

$$
v^{*}=\frac{(1+t) \eta+\sqrt{(1+t)^{2} \eta^{2}-4 \eta g}}{2 \eta}
$$

\section{Numerical examples of PTP Effectiveness}

Assuming that $t=0.5$, Figure 1 shows how this voucher ratio $\left(v^{*}\right)$ is related to hiring responsiveness $(\eta)$ for three different levels of government claw-back $(g)$ : $5 \%, 10 \%$, and $15 \%$ claw-back.

Figure 1: The Voucher Ratio versus Hiring Responsiveness; three levels of government claw-back $(g): 5 \%, 10 \%$, and $15 \%$.

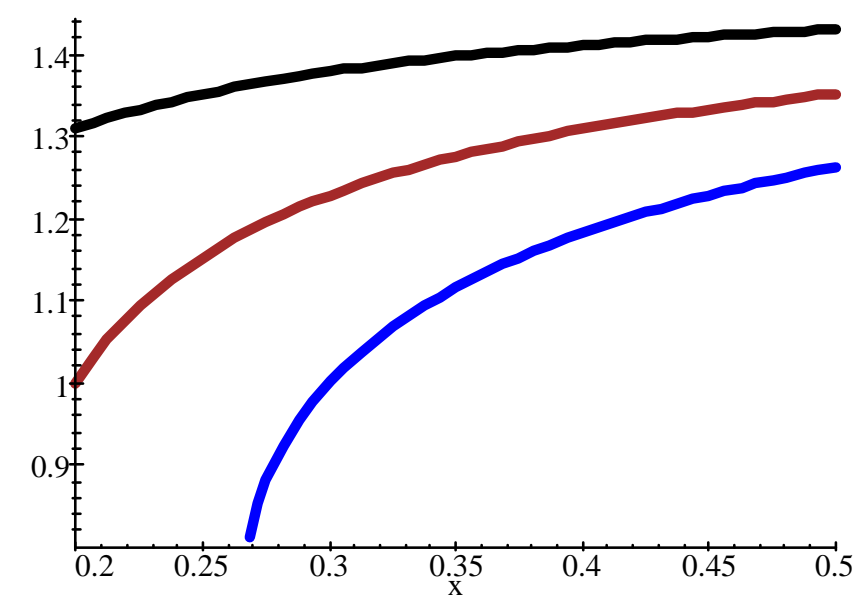

Observe, for example, that if hiring responsiveness is 0.3 , then a government claw-back of $5 \%$, implies an optimal employment voucher ratio of 1.3792 ;a clawback of $10 \%$ implies a voucher ratio of 1.2287 ; and a claw-back of $15 \%$ implies a voucher ratio of 1.0 .

\footnotetext{
${ }^{3}$ If the government's objective were to maximize its pension surplus (or minimize its pension deficit), then it would have to choose a voucher ratio that maximizes the difference between its voucher revenue and its voucher cost: $(1+t) \eta v-\eta v^{2}$. The optimal voucher ratio for this objective is independent of hiring responsiveness $(\eta)$ :

$$
v^{\prime}=\frac{1+t}{2}
$$
}


The employment rates associated with the optimal voucher ratio for the above values of hiring responsiveness and government claw-back are given in Figure 2:

Figure 2: Employment Rate versus Hiring Responsiveness; three levels of government claw-back $(g): 5 \%, 10 \%$, and $15 \%$.

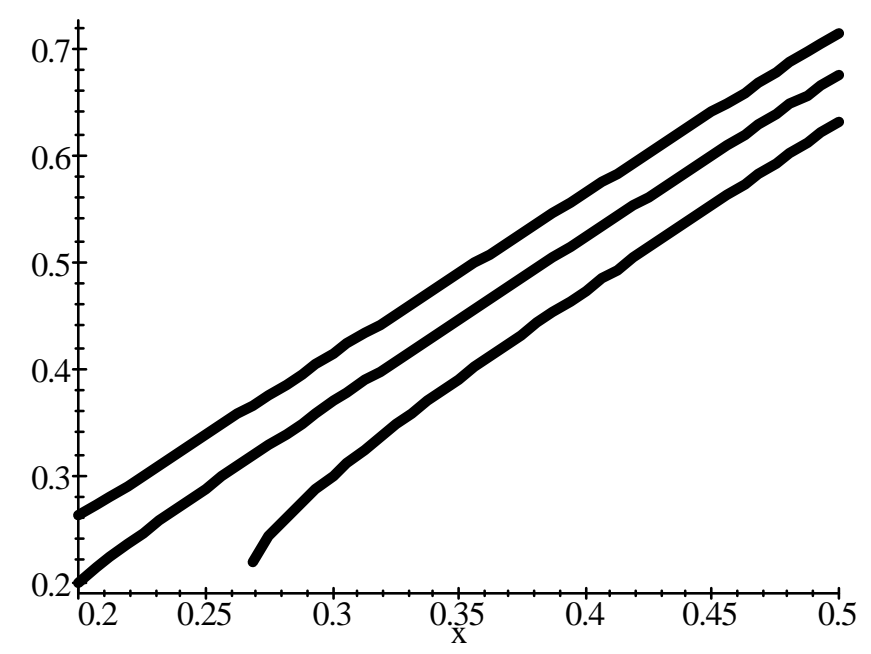

Figure 3 shows the relation between the optimal voucher and hiring responsiveness for three different tax ratios $t=T / B: 0,0.25$, and 0.5 , assuming that the government claw-back proportion is $5 \%$ :

Figure 3: The Voucher Ratio versus Hiring Responsiveness; three different tax ratios: $t=0,0.25,0.5$. 


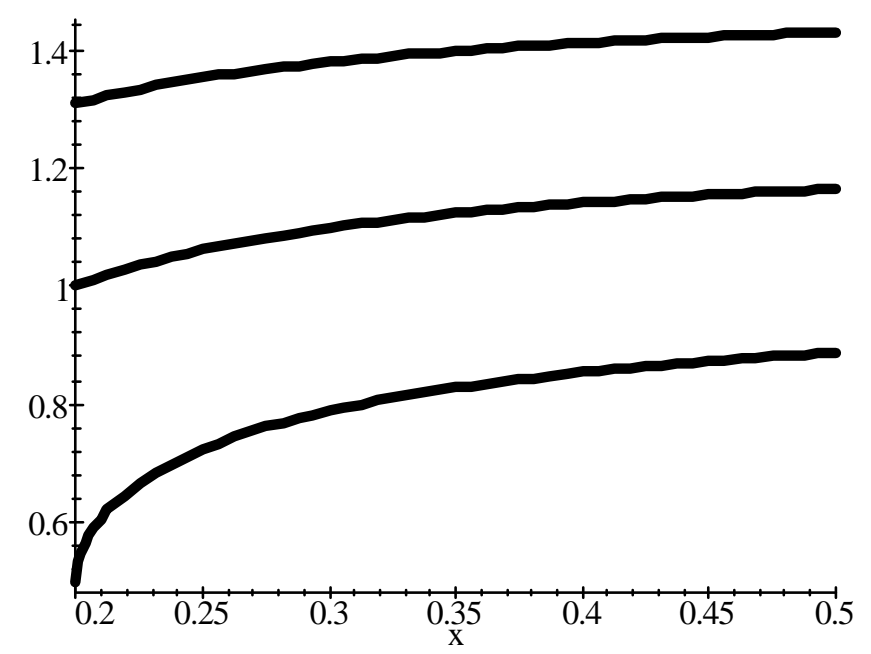

The associated employment rates for people in the target group are pictured in Figure 4:

Figure 4: The Employment Rate versus Hiring Responsiveness;

three different tax ratios: $t=0,0.25,0.5$

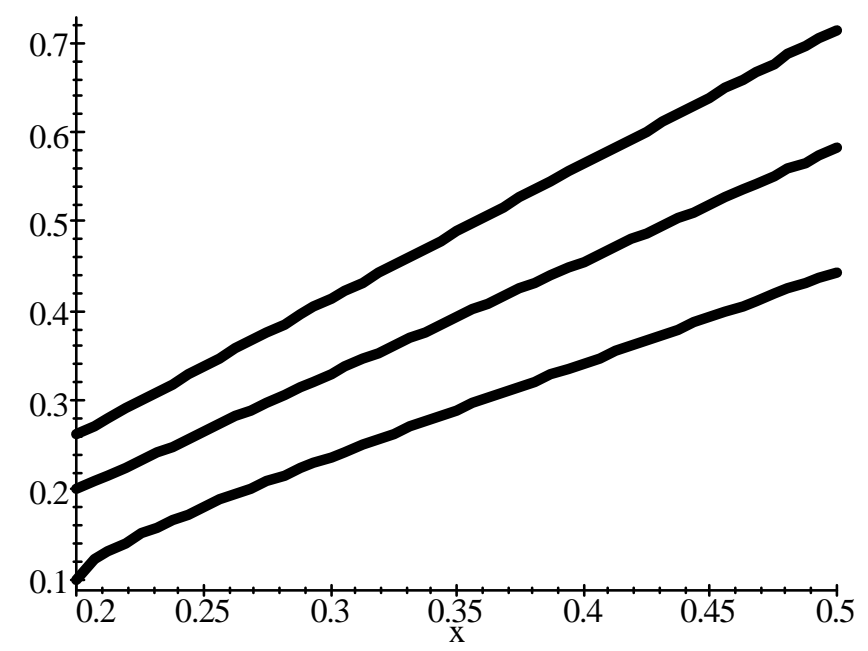




\section{A Simple Model of the PTP for Early Retirement}

We now consider the part of the PTP relating to early retirement. Giving people the option of transferring pensions into employment vouchers before the maximum retirement age has qualitatively similar effects to the ones outlined above, with one exception. Since people who have the right of early retirement are free to work, the effectiveness of the PTP will be reduced on account of deadweight loss: Some of the people who receive the employment vouchers under the program would have remained working even in the absence of the program. For simplicity, we capture this problem be specifying a new linear hiring function as follows:

$$
h(v)=\eta_{0}+\eta_{1} v, \quad \eta_{0}, \eta_{1}>0
$$

We call $\eta_{0}$ the "deadweight loss coefficient," since it specifies how much hiring would have taken place in the absence of the employment voucher.

Substituting this hiring function into the government budget constraint (4), we find that the optimal voucher is the larger root of the equation $\eta_{1} v^{2}+\left(\eta_{0}-(1+t) \eta_{1}\right) v+$ $\left[g-(1+t) \eta_{0}\right]=0$. The solution is

$$
v^{d}=\frac{\left(-\eta_{0}+(1+t) \eta_{1}\right)+\sqrt{\left(\eta_{0}-(1+t) \eta_{1}\right)^{2}-4 \eta\left(g-(1+t) \eta_{0}\right)}}{2 \eta_{1}}
$$

Assuming a government claw-back proportion $g=5 \%$ and a tax ratio $t=0.5$, Figure 5 shows how the optimal voucher depends on hiring responsiveness for three different values of the deadweight loss coefficient: $0.0,0.3$, and 0.6 :

Figure 5: The Voucher Ratio versus Hiring Responsiveness; three different values of the deadweight loss coefficient: $0,0.3,0.6$ 


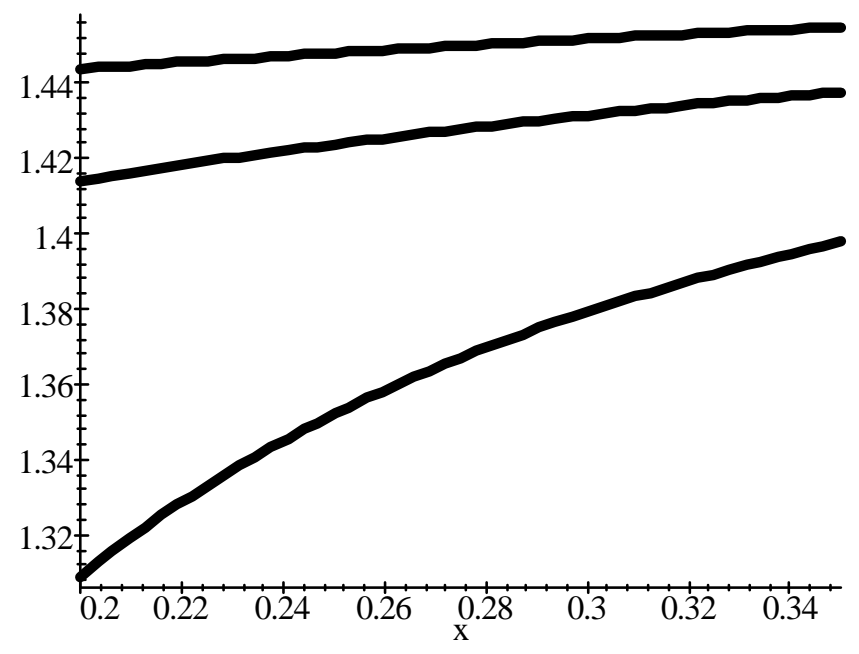

In words, the greater the deadweight loss coefficient, the higher the voucher ratio needs to be in order for the government to recoup $g$. The employment rates associated with this range of optimal voucher ratios is given in Figure 6:

Figure 6: The Employment Rate versus Hiring Responsiveness; three different values of the deadweight loss coefficient: $0,0.3,0.6$

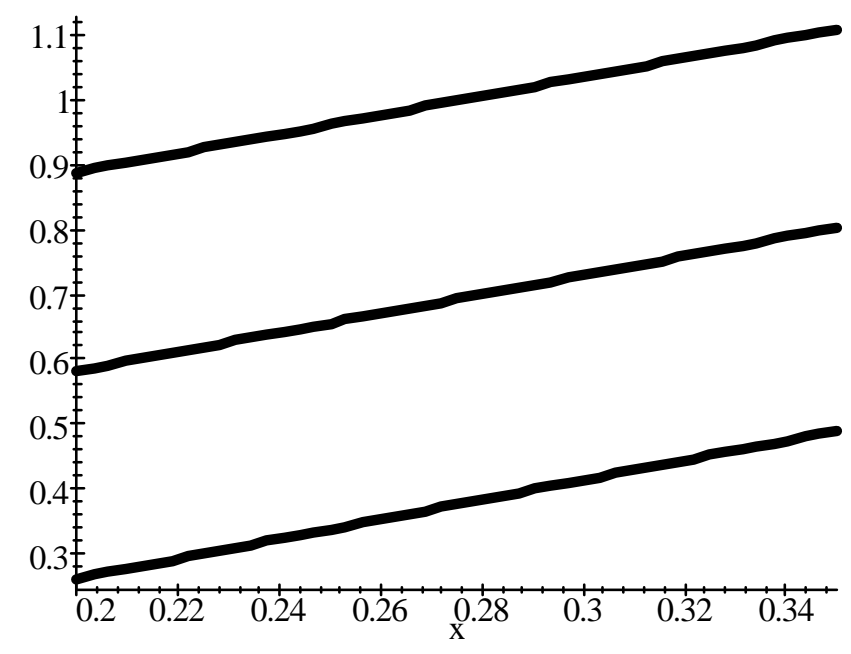




\section{Concluding Thoughts}

Although it is important to keep in mind that the model above is extremely simplified and thus certainly cannot be taken as a practical guide in the formulation of policy, these results are nevertheless striking. First, the indicate that for a range plausible values of hiring responsiveness and reasonable targets for government claw-back, the optimal voucher ratio is remarkably high, possibly even above unity. In other words, to achieve its goal of maximizing employment and recouping a given proportion of its pension outlays, the government needs to set the employment subsidy high in relation to the corresponding pension benefit. The reason is that when the government lets people use some of their pension funds to provide employment vouchers, the government not only keeps a portion of the pension outlay, it also gains tax receipts from the resulting productive activities. Furthermore, since the target group would have remained out of the labor force in the absence of the policy, the PTPs effectiveness is not diminished through "deadweight loss" (the problem that some of the employment vouchers are received by people who would have found jobs even in the absence of the policy).

Second and most importantly, the model above suggests that the PTP may have a useful role to play in reducing governments' pension obligations without making the pensionable workers significantly worse off. The PTP may be expected to achieve this result since it expands the choices available to pensionable workers. Since these new choices are valuable, the PTP helps make pensionable workers and their employers better off, while enabling the government to reduce its pension deficit (or increase its pension surplus). The PTP is able to achieve this outcome by reducing an inefficiency inherent in current pension systems. Employees and employers are diverse. While some employees are happy to retire at the current retirement age, others are not. While some employers are happy to relinquish employees at that age, others want them to stay. There is no economic, psychological, biological, or sociological law dictating that everyone must retire at age 60 , or 65, or any other cutoff point currently used in the OECD. If employers find it useful to fix a retirement age in advance in order to promote incentives to work, in a market economy they are generally free to do so voluntarily. But mandating such a retirement age is likely to be inefficient. Most current pension systems magnify this inefficiency by rewarding workers for retiring earlier than they may otherwise have desired and penalizing them for remaining in the labor force. The nature of inefficiencies is that they waste resources. By reducing such waste, the PTP creates a free lunch that enables pensionable workers, their 
employers, and the government all to be made better off.

\section{References}

\section{References}

[1] OECD (1998), Maintaining Prosperity in an Ageing Society, Paris: OECD.

[2] OECD (1999), OECD Economic Surveys, United States, Special Feature: Coping with Ageing, Paris: OECD. 


\section{IZA Discussion Papers}

No. Author(s)

521

522

S.-Å. Dahl

$\varnothing$. A. Nilsen

$\mathrm{K}$. Vaage

523

J. Falkinger

V. Grossmann

524

J. J. Dolado

F. Felgueroso

J. F. Jimeno

525

J. J. Heckman

C. Heinrich

J. Smith

526

E. Leuven

H. Oosterbeek

527 J. C. van Ours

528

P. Manzini

M. Mariotti

J. M. Orszag

D. Snower

M. Karanassou

D. Snower

M. Karanassou

H. Sala

D. Snower

J. M. Orszag

D. Snower

S. Fölster

R. Gidehag

M. Orszag

D. Snower

A. Lindbeck

D. Snower

535

P. Manzini

D. Snower

536

537

538

D. Snower
J. M. Orszag

D. Snower
Title

Employment Status, Endogenous Regional

Mobility, and Spatial Dependencies in Labor

Markets

Gender Differences in Early Retirement

Behaviour

Workplaces in the Primary Economy and Wage 3

Pressure in the Secondary Labor Market

Recent Trends in Occupational Segregation by

Gender: A Look Across the Atlantic

The Performance of Performance Standards

6

07/02

A New Approach to Estimate the Wage Returns to Work-Related Training

The Locking-in Effect of Subsidized Jobs

4

Arbitration and Mediation: An Economic

Perspective

Incapacity Benefits and Employment Policy

3

Unemployment Invariance

3

Unemployment in the European Union: A

Dynamic Reappraisal

3

07/02

From Unemployment Benefits to Unemployment Accounts

Assessing Welfare Accounts

07/02

07/02

3

3

07/02

The Insider-Outsider Theory: A Survey

3

07/02

Bargaining Power

Pension Taxes versus Early Retirement Rights

3

07/02

Unemployment Vouchers versus Low-Wage

3

07/02

Subsidies

The Pension Transfer Program

D. Snower 